\title{
Richtlijnvoorstel voor grensoverschrijdende omzettingen, fusies en splitsingen: een (geheel) nieuwe stap in het harmonisatieproces
}

\author{
$M r . M . A . V e r b r u g b^{*}$
}

\begin{abstract}
Op 25 april 2018 heeft de Europese Commissie een voorstel voor een nieuwe harmonisatieregeling voor grensoverschrijdende omzettingen en grensoverschrijdende splitsingen en een aanpassing van de bestaande regels inzake grensoverschrijdende fusies openbaar gemaakt. In deze bijdrage wordt het voorstel kritisch onderzocht.
\end{abstract}

\section{Inleiding}

Op 25 april 2018 heeft de Europese Commissie twee richtlijnvoorstellen openbaar gemaakt. Het gaat om een voorstel voor een richtlijn tot wijziging van Richtlijn 2017/1132 met betrekking tot grensoverschrijdende omzettingen, fusies en splitsingen, en om een voorstel voor een richtlijn tot wijziging van dezelfde richtlijn met betrekking tot het gebruik van digitale instrumenten en processen in het kader van het vennootschapsrecht. ${ }^{1}$ Het eerste voorstel behelst een geheel nieuwe harmonisatieregeling voor grensoverschrijdende omzettingen en splitsingen ${ }^{2}$ en een aanpassing van de bestaande regels inzake grensoverschrijdende fusies. Het meest opvallende element in dit voorstel is het streven schijnconstructies en misbruik tegen te gaan.

Het tweede voorstel voorziet (voor de BV verplicht) in volledige online oprichting en registratie van vennootschappen en bijkantoren en volledige online indiening van documenten en gegevensverplichtingen. Dat laatste is ook voor grensoverschrijdende structuurwijzigingen relevant. Voor de BV moet registratie mogelijk worden aan de hand van modellen van oprichtingsakten die online beschikbaar zijn. Ook in het tweede voorstel speelt, naast (digitale) facilitering van vennootschappen, het voorkómen van fraude en misbruik een rol.

\footnotetext{
Mr. M.A. Verbrugh is universitair hoofddocent ondernemingsrecht aan de Erasmus School of Law.

1. $\operatorname{COM}(2018) 241$ final, resp. $\operatorname{COM}(2018) 239$ final. Voor beide voorstellen sloot op 30 juni 2018 de Nederlandse internetconsultatie.

2. Zie voor een regeling voor grensoverschrijdende omzetting en splitsing ook de European Model Company Act (EMCA) 2017. De EMCA is een door onafhankelijke experts uit verschillende lidstaten opgestelde modelwet voor vennootschapsrecht, bedoeld voor lidstaten om geheel of gedeeltelijk over te nemen.
}

In deze bijdrage wordt het richtlijnvoorstel voor grensoverschrijdende omzettingen, fusies en splitsingen onderzocht. ${ }^{3}$ Hieronder worden allereerst de - voor een goed begrip van de plannen nodige - achtergrond en ruimere context van het voorstel besproken. ${ }^{4}$ Vervolgens zal afzonderlijk worden ingegaan op grensoverschrijdende omzetting, grensoverschrijdende fusie en grensoverschrijdende splitsing. Daar waar een onderwerp voor alle drie de structuurwijzigingen geldt, zal het (vooral) bij omzetting aan de orde komen. Onderwerpen die zowel voor fusie als voor splitsing gelden, komen (vooral) bij fusie aan de orde.

In een volgende bijdrage zal het voorstel met betrekking tot het gebruik van digitale instrumenten en processen worden onderzocht.

\section{Achtergrond}

Binnen de interne markt is het niet alleen belangrijk dat activiteiten over de grens kunnen worden ondernomen, maar tevens dat grensoverschrijdende structuurwijzigingen kunnen plaats-

3. Gezien het complexe en grote onderwerp van werknemersmedezeggenschap, zal daaraan geen aandacht worden besteed. Zie daarvoor bij fusie F.G. Laagland, De rol van Nederlandse werknemers(vertegenwoordigers) bij een grensoverschrijdende juridische fusie (diss. Nijmegen), Deventer: Kluwer 2013. Zie voor grensoverschrijdende omzetting J.J. van den Broek \& G.J.C. Rensen (red.), Grensoverschrijdende omzetting van rechtspersonen. Civiel en fiscaal recht, Deventer: Wolters Kluwer 2018 Zie voor grensoverschrijdende fusie G. van Solinge, Grensoverschrijdende juridische fusie (diss. Amsterdam VU), Deventer: Kluwer 1994; H.J.M.M. van Boxel, Grensoverschrijdende fusies van kapitaalvennootschappen naar Nederlands recht (diss. Nijmegen), Deventer: Kluwer 2011. Zie voor grensoverschrijdende splitsing E.R. Roelofs, Grensoverschrijdende splitsing van kapitaalvennootschappen (diss. Utrecht), Deventer: Kluwer 2014. Zie voor fusie en splitsing D.F.M.M. Zaman, G.C. van Eck \& E.R. Roelofs, Nationale en grensoverschrijdende juridische fusie $\&$ juridische splitsing van kapitaalvennootschappen. Een praktische civielrechtelijke analyse, Den Haag: Sdu Uitgevers 2009.

4. Zie daarover verder J.N. Schutte-Veenstra, Europees vennootschapsrecht (Serie Ondernemingsrecht, deel A-15), Den Haag: Sdu Uitgevers 2013; M.L. Lennarts e.a., Europa! Europa? De invloed van het Europese vennootschaps- en effectenrecht nu en in de toekomst (Preadvies van de Vereeniging 'Handelsrecht'), Deventer: Kluwer 2012. 
vinden. Bij die mogelijkheid speelt grensoverschrijdende fusie een voortrekkersrol, zij het met een lange aanloop. Nadat een poging te komen tot een verdrag was mislukt, nationale fusieregels met de Derde richtlijn ${ }^{5}$ uit 1978 waren geharmoniseerd, en de voor de SE in 2001 tot stand gekomen oplossing voor het probleem van werknemersmedezeggenschap was overgenomen, is in 2005 de richtlijn inzake grensoverschrijdende fusies van kapitaalvennootschappen (hierna: de Tiende richtlijn) aangenomen. ${ }^{6}$ De Tiende richtlijn bevat een aantal bepalingen die te maken hebben met het grensoverschrijdende karakter van de rechtshandeling, en verwijst voor het overige naar de Derde richtlijn. Voor splitsing geldt met de Zesde richtlijn ${ }^{7}$ dat alleen regels voor nationale (zuivere) splitsingen zijn geharmoniseerd. Voor nationale omzetting bestaat geen geharmoniseerde regelgeving in de EU. ${ }^{8}$

In 2007 is een versoepeling uit de Tiende richtlijn overgenomen in de Derde en Zesde richtlijn, en vervolgens zijn de Derde, Zesde en Tiende richtlijn in 2009 verder versoepeld. ${ }^{9}$ Daarmee kunnen aandeelhouders onder meer afzien van een bestuursverslag en een verklaring van een deskundige. Uit het nieuwe voorstel van 25 april 2018 blijkt dat de regels voor grensoverschrijdende fusies volgens de Commissie nog (steeds) voor verbetering vatbaar zijn. In 2017 zijn, naast de Eerste en Tweede richtlijn, de Derde, Zesde en Tiende richtlijn gecodificeerd in Richtlijn 2017/1132. ${ }^{10}$ Daarbij hebben geen inhoudelijke wijzigingen plaatsgevonden, maar zijn (de laatste versies van) deze richtlijnen samengenomen in één richtlijn.

Voor grensoverschrijdende splitsing heeft de Commissie tot 25 april 2018 geen initiatief tot wetgeving genomen. Wel was de Commissie, hiertoe aangezet door de High Level Group of Company Law Experts, al in 2003 voornemens hiertoe op korte termijn over te gaan. Dit voornemen gold in 2003 ook voor grensoverschrijdende fusie en grensoverschrijdende omzetting. ${ }^{11}$ Regulering van grensoverschrijdende omzetting heeft in het verleden wel de nodige aandacht van de Commissie en aansporing door het Europees Parlement gekregen, maar tot

5. Richtlijn 78/855/EEG.

6. Richtlijn 2005/56/EG. Het voorstel begon als Tiende richtlijn, nadien is de nummering losgelaten.

7. Richtlijn 82/891/EEG. De richtlijn dwingt niet tot invoering van een splitsingsregeling, maar wel tot het naleven van de richtlijn bij invoering daarvan. De Derde en Zesde richtlijn zien alleen op NV's, maar zijn door de lidstaten ruimer geïmplementeerd. Zie voor het onderscheid in Nederland tussen zuivere splitsing en afsplitsing, art. 2:334a BW.

8. Zie voor omzetting B. Snijder-Kuipers, Omzetting als rechtsvormwijziging (diss. Groningen), Deventer: Kluwer 2010 en M.A. Verbrugh (diss. Rotterdam), Structuurwijzigingen bij kapitaalvennootschappen en de positie van schuldeisers, Deventer: Kluwer 2007.

9. Zie Richtlijn 2007/63/EG en Richtlijn 2009/109/EG. Zie hierover M.A Verbrugh, Versoepeling van de fusie- en splitsingsprocedure in etappes, TvJ 2010, afl. 4, p. 107-115.

10. Voor de eenvoud zal hieronder nog worden gesproken van Zesde en Tiende richtlijn.

11. Zie COM(2003)284. Zie ook het 'Report of the Reflection Group on the Future of EU Company Law' uit 2011 en het actieplan van de Commissie uit 2012, $\operatorname{COM}(2012) 740$. april 2018 met weinig resultaat tot gevolg. ${ }^{12}$ Deze besluiteloosheid heeft Nederland er in 2014 toe gebracht een internetconsultatie over een ambtelijk voorontwerp inzake grensoverschrijdende omzetting van kapitaalvennootschappen te houden. ${ }^{13}$

Het ontbreken van een wettelijke regeling voor een grensoverschrijdende structuurwijziging betekent niet dat zij onmogelijk zou zijn. Uit het Sevic-arrest blijkt dat grensoverschrijdende fusie valt onder de vrijheid van vestiging (art. 49 en 54 van het Verdrag betreffende de werking van de Europese Unie (VWEU)). ${ }^{14}$ Uit het arrest volgt tevens dat ook 'overige omzettingen van vennootschappen' bijzondere wijzen van uitoefening van de vrijheid van vestiging vormen, waarvoor de lidstaten de vrijheid van vestiging moeten eerbiedigen. ${ }^{15} \mathrm{Bij}$ overige omzettingen kan worden gedacht aan grensoverschrijdende omzetting en splitsing. Voor omzetting heeft het Hof van Justitie van de EU deze mogelijkheid nadien bevestigd. ${ }^{16}$

Vanuit Nederland bezien komen met name grensoverschrijdende omzettingen - met een beroep op de vrijheid van vestiging - met enige regelmaat voor. ${ }^{17}$ Het ontbreken van geharmoniseerde wettelijke regels in de EU geldt als belangrijkste reden voor een (zeer) terughoudend gebruik van grensoverschrijdende splitsing en omzetting. Niet goed aansluitende regels, lacunes en botsende bepalingen kunnen tot problemen en rechtsonzekerheid leiden. Belangen van stakeholders, zoals (minderheids)aandeelhouders, schuldeisers en werknemers, kunnen in het gedrang komen. Het nieuwe voorstel van de Commissie heeft daarom twee doelstellingen voor ogen: het bevorderen van grensoverschrijdende mobiliteit in de EU en tegelijkertijd de belanghebbenden van vennootschappen passende bescherming bieden 'om de billijkheid van de eengemakte markt te waarborgen' ${ }^{18}$

12. Zo heeft jaren geleden een informele versie voor een ontwerp voor een Veertiende richtlijn gecirculeerd en hebben diverse impact assessments plaatsgevonden. Zie verder bijv. de Resoluties van het EP, 2008/2196(INI) en 2011/2046(INI). De SE-Verordening (SE-VO) kent in art. 8 wel een regeling voor grensoverschrijdende statutaire zetelverplaatsing.

13. Zie https://www.internetconsultatie.nl/grensoverschrijdende_omzetting/ details. Zie ook Lennarts e.a. 2012.

14. HvJ EG 13 december 2005, C-411/03. Tevens kan door grensoverschrijdende fusie van NV's uit verschillende lidstaten een SE worden opgericht, art. 2 SE-VO.

15. R.o. 19.

16. Zie HvJ EG 16 december 2008, C-210/06 (Cartesio); HvJ EU 12 juli 2012, C-387/10 (Vale) en HvJ EU 25 oktober 2017, C-106/16 (Polbud). Zie verder M.A. Verbrugh, Cartesio: baanbrekend of wegbereidend? SEW 2009, afl. 11, p. 419-428; M.A. Verbrugh, Grensoverschrijdende omzetting na de arresten Cartesio en Vale, SEW 2014, afl. 11, p. 512-523 en M.A. Verbrugh, Grensoverschrijdende zetelverplaatsing op grond van de vrijheid van vestiging: het laatste stukje van de puzzel in het Polbud-arrest?, TAO 2018, afl. 1, p. 14-22.

17. Zie G.J.C. Rensen \& K.J. Bakker, Grensoverschrijdende omzetting in de praktijk, WPNR 2016/7116, p. 593-601.

18. Zie het voorstel, p. 2. Zie verder, p. 4, 6-7 en 9. Zie over deze balans bij fusie, splitsing en omzetting, Verbrugh 2007 , en meer in het algemeen B.F. Assink, De Januskop van het ondernemingsrecht. Over faciliëring en regulering van ondernemerschap (oratie Rotterdam), Deventer: Kluwer 2010 . 


\section{Maandblad \\ Ondernemingsrecht}

Wat betreft de bescherming van belanghebbenden in het voorstel vallen twee dingen op. Allereerst de grote aandacht voor bescherming van stakeholders (in ruime zin). ${ }^{19}$ Het gaat daarbij zowel om een versterking van de bescherming van aandeelhouders, schuldeisers en werknemers als om fiscale aangelegenheden. Bij de start van het harmonisatieprogramma in de jaren zestig van de vorige eeuw lag de nadruk sterk op het beschermen van deelnemers, zoals aandeelhouders, en derden. Geharmoniseerde bescherming in de EU moest een race to the bottom voorkomen. ${ }^{20}$ Met de instelling van de High Level Group of Company Law Experts in 2001 vond bij de Commissie een duidelijke verschuiving in doelstelling van Europees vennootschapsrecht plaats, van bescherming naar facilitering van ondernemerschap. ${ }^{21}$ Met dit nieuwe voorstel lijkt de pendule weer (stevig) terug te zwaaien.

Ten tweede valt bij de bescherming van belanghebbenden in het voorstel op dat een belangrijk onderdeel - en dan gek genoeg alleen voor omzettingen en splitsingen - ziet op het tegengaan van kunstmatige constructies om onterechte belastingvoordelen te behalen. Dat is niet alleen nieuw en ogenschijnlijk problematisch, maar lijkt tevens overbodig door de reeds bestaande fiscale Europeesrechtelijke regels. ${ }^{22}$ Los van mogelijke praktische bezwaren, die hieronder aan de orde komen, worden hiermee fiscale doelstellingen in civielrechtelijke wetgeving voor structuurwijzigingen binnengehaald. ${ }^{23}$

\section{Grensoverschrijdende omzettingen}

\subsection{Inleiding}

De voorgestelde regeling voor grensoverschrijdende omzetting is in opzet en procedure in hoofdlijnen hetzelfde als die van grensoverschrijdende fusie en splitsing. Er kan een onderscheid worden gemaakt tussen de voorbereidende fase, de besluitvormende fase en de uitvoerende fase. ${ }^{24}$

Bij een grensoverschrijdende omzetting wijzigt de rechtsvorm van een lidstaat in een rechtsvorm van een andere lidstaat, onder gelijktijdig voortbestaan van de rechtspersoon. Daarbij

19. Het woord 'bescherm', met daaronder bescherming, beschermen, beschermd, enz., komt 142 keer voor en 'waarborg' 54 keer in het document van 97 pagina's.

20. Zie M.J. Kroeze \& H.M. Vletter-van Dort, Eenvormig bedrijfsrecht: een oud deuntje of toekomstmuziek?, in: F. de Ly \& W.H. van Boom (red.), Eenvormig bedrijfsrecht: realiteit of utopie, Den Haag: Boom Juridische uitgevers 2006, p. 73-92.

21. Zie Report of the High Level Group of Company Law Experts on a Modern Regulatory Framework for Company Law, 2002, p. 29-30; EMCA 2017, p. 6.

22. Zie de reactie op de consultatie van de NOB van 29 juni 2018, te vinden via: https://www.internetconsultatie.nl/grensoverschrijdendeomzetting fusiesplitsing/reacties.

23. Zie kritisch: de reactie van de NOB van 29 juni 2018; G.T.K. Meeusen, Het richtlijnvoorstel met betrekking tot grensoverschrijdende omzettingen, fusies en splitsingen: een opmerkelijke paragraaf, NTFR 2018/1329. Door de fiscale verwevenheid zouden volgens de NOB niet art. 50 en 114(1) VWEU, maar art. 115 VWEU als grondslag moeten dienen, en zou daarmee unanimiteit nodig zijn voor aanneming van de richtlijn.

24. Zie Asser/Kroeze 2-I* 2015/431, 462 en 474. wordt de statutaire zetel verplaatst naar de lidstaat van bestemming (verder: het gastland). ${ }^{25}$ Alleen wanneer het gastland de werkelijke-zetelleer hanteert, zal ook de werkelijke zetel moeten meeverhuizen. Dat volgt niet uit het richtlijnvoorstel, maar uit het feit dat in Europa zowel de incorporatieleer als de werkelijke-zetelleer bestaat. ${ }^{26}$

Het voorstel ziet alleen op kapitaalvennootschappen, hetgeen niet wordt gemotiveerd. ${ }^{27}$ Hoewel deze beperking vanuit het oogpunt van eenvoud te begrijpen is, is de definitie van vennootschappen uit artikel $54 \mathrm{VWEU}$, en daarmee van vennootschappen die grensoverschrijdend kunnen omzetten, ruimer.

\subsection{Omzettingsprocedure}

De onderwerpen die in het voorstel voor een grensoverschrijdende omzetting (verder: omzetting) moeten worden opgenomen, volgen in hoofdlijnen de onderwerpen die gelden bij een grensoverschrijdende fusie (verder: fusie) en grensoverschrijdende splitsing (verder: splitsing).$^{28}$ Nieuw ten opzichte van de huidige fusieregeling en voorgesteld voor fusie, splitsing en omzetting, is dat in het voorstel tevens wordt vermeld 'een nadere omschrijving van de aan de schuldeisers geboden waarborgen'. ${ }^{29}$ Hetzelfde geldt voor de optie aan lidstaten om het bestuur te verplichten een verklaring over de financiële toestand van de vennootschap in het voorstel op te nemen. ${ }^{30}$ Nieuw is tevens de toevoeging dat naast de officiële talen van de betrokken lidstaten, de lidstaten moeten toestaan dat de vennootschap zich bedient van een taal die in de internationale zakelijke en financiële wereld gangbaar is voor het opstellen van het voorstel en van alle andere desbetreffende documenten.

Anders dan in de huidige fusieregeling en nieuw voorgesteld voor omzetting, fusie en splitsing, geldt dat het bestuur niet één, maar twee afzonderlijke verslagen opstelt: een verslag aan de deelnemers (aandeelhouders) en een verslag aan de werknemers. ${ }^{31}$ In het eerste verslag worden de wettelijke en economische aspecten van de omzetting (fusie of splitsing) toegelicht en verantwoord. Daarin komen onder meer de gevolgen voor de toekomstige bedrijfsactiviteiten van de vennootschap en voor het strategisch plan van het bestuur aan de orde. Evenals

25. Zie art. 86 ter sub 2. De definitie in sub 6 van 'omgezette vennootschap' als 'nieuw opgerichte vennootschap' moet dan ook niet als nieuw opgerichte rechtspersoon worden gelezen. Met nieuw opgerichte vennootschap wordt uitgedrukt dat aan de oprichtingsvereisten van het gastland moet worden voldaan.

26. Zie ook Verbrugh 2018.

27. Zie art. 86 bis en art. 86 ter sub 1 . Ook het Nederlandse ambtelijk voorontwerp ziet alleen op kapitaalvennootschappen.

28. Zie art. 86 quinquies. Zie voor fusie p. 68 , nr. 6 en art. 122 Richtlijn $2017 / 1132$, en voor splitsing art. 160 sexies.

29. Bij fusie en splitsing gaat het om 'details van de waarborgen voor schuldeisers'.

30. Zie voor beide verder par. 3.4.

31. Zie art. 86 sexies en septies. Zie voor fusie p. 71 (waar onder art. 124 lid 2 sub e ten onrechte 'omzetting' staat), en voor splitsing art. 160 octies en nonies. In het huidige fusieverslag moeten weliswaar de gevolgen voor de werknemers (en schuldeisers) worden toegelicht, maar is het een verslag voor de aandeelhouders. Zie art. 124 Richtlijn 2017/1132. 
bij het huidige fusieverslag kan van het verslag worden afgezien wanneer alle aandeelhouders daarmee instemmen. In het tweede verslag worden de gevolgen voor de werknemers toegelicht. Dit recht op informatie moet niet worden verward met de medezeggenschapsregels in het richtlijnvoorstel, die zien op het waarborgen van de bestaande vennootschapsrechtelijke medezeggenschap. ${ }^{32}$

Een onafhankelijke deskundige stelt een schriftelijk verslag op met daarin een gedetailleerde beoordeling van de nauwkeurigheid van de verslagen en de informatie die zijn ingediend. Kleine en micro-ondernemingen zijn bij omzetting en splitsing vrijgesteld van het onderzoek door een onafhankelijke deskundige. ${ }^{33}$ In de toelichting wordt als argument voor de vrijstelling het evenredigheidsbeginsel genoemd. ${ }^{34}$ Onduidelijk is waarom de vrijstelling niet wordt voorgesteld voor fusie. Hoewel zorg voor regeldruk begrijpelijk is, is de vraag of onafhankelijk onderzoek niet juist bij deze kleine ondernemingen nodig is, nu veelal minder budget en juridische expertise aanwezig zullen zijn. Uit de toelichting volgt dat vermoedelijk een aanzienlijk deel van de ondernemingen in Europa onder de vrijstelling zal vallen. ${ }^{35}$

Opvallend aan de openbaarmakingsverplichting voor het voorstel en het verslag van de onafhankelijke deskundige bij omzetting en splitsing is dat tevens een kennisgeving aan de deelnemers, schuldeisers en werknemers moet worden gedaan, dat zij bij de vennootschap en bij de bevoegde instantie opmerkingen kunnen indienen over beide documenten. ${ }^{36}$ Zowel bij omzetting als bij fusie en splitsing kunnen lidstaten de vennootschap vrijstellen van de in lid 1 bedoelde openbaarmakingsverplichting, indien zij de documenten gedurende een zekere periode kosteloos op haar website beschikbaar stelt.

Evenals bij fusie en splitsing moet het voorstel voor omzetting door de algemene vergadering worden goedgekeurd. ${ }^{37}$ De voor omzetting en splitsing voorgestelde regelingen blinken niet uit in helderheid en lijken niet goed doordacht. Uit artikel 86 decies lid 3 volgt dat een meerderheid is vereist voor de goedkeuring van wijzigingen in het voorstel van niet minder dan twee derde, maar niet meer dan $90 \%$ van de stemmen. Tevens is te lezen dat de drempel voor de stemming in elk geval niet hoger is dan die waarin het nationale recht voorziet voor de

32. Zie daarvoor art. 86 terdecies, voor fusie p. 77 , nr. 17 en voor splitsing, art. 160 quindecies.

33. Zie art. 86 octies lid 3 sub a en lid 6, en voor splitsing art. 160 decies lid 3 sub e en lid 6, waarin het gaat om een 'gedetailleerde evaluatie van de accuraatheid'. Evenals bij fusie onderzoekt de deskundige ook de ruilverhouding. Zie voor de rol van de onafhankelijke deskundige ook hieronder over controle op kunstmatige constructies.

34. Voorstel, p. 26.

35. Zie voorstel, p. 1. Hoewel uit de daar genoemde gegevens niet blijkt hoeveel ondernemingen onder Aanbeveling 2003/361 EG vallen, is aannemelijk dat het om een groot aantal gaat.

36. Zie art. 86 nonies en voor splitsing art. 160 undecies. Zie voor fusie p. 69 , nr. 8.

37. Zie art. 86 decies en voor splitsing art. 160 duodecies. Art.126 lid 3 Richtlijn 2017/1132 biedt lidstaten de optie een uitzondering te maken voor de verkrijgende vennootschap. goedkeuring van grensoverschrijdende fusie. Bij nadere bestudering blijkt dat 'de stemming' niet kan zien op het besluit tot wijziging van het voorstel, maar (alleen) op de goedkeuring van het besluit zelf. Daar duidt niet alleen de toelichting op, ${ }^{38}$ waarin het gaat over het besluit tot goedkeuring van het voorstel, maar ook het feit dat (als de lidstaten daarvoor kiezen) een fusie met een gewone meerderheid van stemmen kan worden genomen, indien meer dan de helft van het geplaatste kapitaal vertegenwoordigd is. ${ }^{39}$ Dit heeft als merkwaardig gevolg dat een wijziging van het voorstel tot omzetting of splitsing strenger wordt behandeld dan het voorstel tot omzetting of splitsing zelf.

Het richtlijnvoorstel somt in artikel 86 quater een aantal voorwaarden betreffende een omzetting op. ${ }^{40}$ Daarvan is het meest opvallend lid 3, waar is te lezen:

'De lidstaten dragen er zorg voor dat de bevoegde instantie van de lidstaat van vertrek de grensoverschrijdende omzetting niet toestaat wanneer zij na een onderzoek (...) vaststelt dat sprake is van een kunstmatige constructie die bedoeld is om onterechte belastingvoordelen te verkrijgen of de wettelijke of contractuele rechten van werknemers, schuldeisers of minderheidsdeelnemers aan te tasten.'

Eenzelfde bepaling is opgenomen in de splitsingsregeling, ${ }^{41}$ maar ontbreekt in de fusieregeling. ${ }^{42}$ Voor het onderzoek, dat is vereist om het aan de omzetting (of splitsing) voorafgaande attest te kunnen afgeven en dat na het besluit van de algemene vergadering kan worden aangevraagd, ${ }^{43}$ heeft de instantie (slechts) een maand de tijd. Wanneer de bevoegde instantie ernstige vermoedens heeft dat de omzetting (of splitsing) een kunstmatige constructie is, kan zij - binnen twee maanden een diepgaande beoordeling verrichten. ${ }^{44}$ De bevoegde instantie wordt hierbij (sterk) geholpen door het onderzoek dat de hiervoor genoemde onafhankelijke deskundige moet uitvoeren. ${ }^{45}$

38. Voorstel, p. 27.

39. Zie art. 126 en 93 Richtlijn 2017/1132.

40. Zie art. 86 quater. Vgl. p. 67 , nr. 4 voor een aanpassing van de fusieregeling. Waar in het eerste geval onder sub c staat 'er loopt een surseance van betaling', staat in het tweede geval onder sub c 'een staking van betaling gaande is'.

41. Art. 160 quinquies lid 3 (waar ten onrechte fusies in de titel staat).

42. Wel kent art. 121 Richtlijn 2017/1132 de mogelijkheid voor (autoriteiten van) lidstaten zich te verzetten tegen een fusie om redenen van algemeen belang. Anders dan bij de SE (zie art. 7 Uitvoeringswet) heeft de Nederlandse wetgever hiervan geen gebruik gemaakt.

43. Zie voor het attest art. 86 quaterdecies en 86 sexdecies, en voor het toezicht in het gastland art. 86 septdecies. Zie voor fusie art. 127 en 128 Richtlijn 2017/1132. Zie voor splitsing art. 160 sexdecies, 160 octodecies en 160 novodecies.

44. Art. 86 quindecies. Zie voor splitsing (waar staat 'diepgaande evaluatie') art. 160 septdecies. Lid 1 suggereert dat een diepgaande beoordeling/evaluatie altijd plaatsvindt, uit lid 2 volgt dat de instantie hiertoe kan besluiten. Uit de toelichting, p. 28, blijkt dat het in dat geval gaat om 'ernstig vermoedens' van een kunstmatige constructie.

45. Zie art. 86 octies, en voor splitsing art. 160 decies. Nu kleine en microondernemingen zijn vrijgesteld van dit onderzoek (zie lid 6), geldt deze hulp in dat geval niet. 


\section{Maandblad \\ Ondernemingsrecht}

Het betreft een vergaande bescherming ex ante door een externe instantie, waarvan zeer de vraag is of zij, ook met hulp van het onderzoek door de onafhankelijke deskundige bij andere dan kleine ondernemingen, hiertoe in staat is. Het gaat met onterechte belastingvoordelen en met aantasting van de rechten van stakeholders om hele verschillende onderwerpen, en onduidelijk is bovendien wat onder onterechte belastingvoordelen en aantasting van rechten precies moet worden verstaan. Zo worden met veel herstructureringen belastingvoordelen beoogd en zullen bij een grensoverschrijdende structuurwijziging al snel bepaalde rechten van stakeholders in meer of mindere mate worden aangetast, onder meer omdat het toepasselijke vennootschapsrecht wijzigt. ${ }^{46}$ Voorts gaat het om complexe onderwerpen, waarbij de instantie van de lidstaat van vertrek tevens moet overzien wat de gevolgen in het gastland zijn. Wat betreft de aantasting van rechten zal het bij omzetting vooral gaan om wettelijke rechten, nu contracten geen wijziging ondergaan door de omzetting. De bepaling in lid 3 suggereert overigens dat desondanks (de gevolgen voor) de contracten moeten worden onderzocht. Als er zorgen bestaan over de aantasting van de positie van deze stakeholders, ligt het meer voor de hand het initiatief voor actie bij hen te leggen. Zoals in de volgende paragrafen zal blijken, is daar ook voor gekozen bij de specifieke bescherming voor deze stakeholders. Daarmee kan, naast het onderzoek naar onterechte belastingvoordelen, ${ }^{47}$ het onderzoek door de bevoegde instantie van de lidstaat van vertrek bij omzetting en splitsing worden gemist.

De omzetting wordt van kracht op de datum van inschrijving van de omgezette vennootschap in de lidstaat van bestemming. ${ }^{48} \mathrm{Net}$ als geldt voor een fusie en wordt voorgesteld voor een splitsing kan een omzetting niet worden nietigverklaard. ${ }^{49}$

\subsection{Bescherming van (minderheids)aandeelhouders}

Een voor aandeelhouders belangrijke regeling is te vinden in artikel 86 undecies. Een gelijke regeling is opgenomen voor fusie en splitsing. ${ }^{50}$ Daarin wordt een vrij uitgebreide uittreedregeling uitgewerkt voor aandeelhouders die niet hebben ingestemd met het voorstel en voor houders van aandelen zonder stemrecht. Onduidelijk is of aandeelhouders tegen moeten hebben gestemd, zoals bijvoorbeeld in Nederland in artikel 2:333h van het Burgerlijk Wetboek (BW) voor een outbound fusie expliciet is opgenomen. Bij de vervreemding in ruil voor een passende vergoeding in geld gaan de aandelen over op de vennootschap, op de overblijvende aandeelhouders of op derden, met instemming van de vennootschap. Het artikel voor-

46. Zie wat betreft belastingvoordelen verder Meeusen 2018 en de reactie op de consultatie van de NOB. Ook wijzen zij op verschillen in terminologie in het voorstel en andere wettelijke regels en rechtspraak.

47. Zie daarvoor par. 2 hierboven.

48. Art. 86 novodecies. Zie voor splitsing art. 160 unvicies.

49. Zie art. 86 duovicies, en voor splitsing art. 160 quatervicies, waar andere bewoordingen worden gebruikt dan bij omzetting en ten onrechte staat 'de procedure tot omzetting'.

50. Voorstel, p. 72-73, nr. 12, resp. art. 160 quaterdecies. De woorden wijken iets af van de regeling voor omzetting. Zie voor fusie ook par. 4 hieronder. ziet tevens in een recht de vergoeding voor de rechter aan te vechten.

\subsection{Bescherming van schuldeisers}

In vergelijking met de huidige fusieregeling stelt het richtlijnvoorstel voor schuldeisers een grotendeels nieuwe aanpak voor die zal gelden voor alle drie de structuurwijzigingen, met een aanvulling voor splitsing. ${ }^{51} \mathrm{Nu}$ het vermogen van de vennootschap - anders dan bij fusie en splitsing - bij omzetting niet wijzigt, is niet vanzelfsprekend dat eenzelfde regime geldt. De bescherming bij omzetting komt daarmee wat vergaand over. ${ }^{52}$ Daar staat tegenover dat eenzelfde regime het voordeel van de eenvoud heeft en dat van de mogelijkheid tot bescherming die wordt geboden bij omzetting minder vaak gebruik zal worden gemaakt, en de regeldruk daarmee in de praktijk wordt beperkt.

In deze nieuwe aanpak worden schuldeisers geholpen bij de beoordeling of de structuurwijziging nadelige gevolgen voor hen met zich zal brengen. Lidstaten mogen het bestuur verplichten in het voorstel een verklaring te laten opnemen waarin de financiële toestand van de vennootschap nauwkeurig wordt weergegeven, aldus lid 1. Daarin wordt vermeld dat het bestuur na redelijke onderzoeksinspanningen ${ }^{53}$ niet op de hoogte is van enige redenen waarom de vennootschap na de omzetting niet in staat zou zijn te voldoen aan haar verplichtingen wanneer deze opeisbaar worden. $\mathrm{Nu}$ de regeling niet ingaat op mogelijke gevolgen van een dergelijke verklaring voor schuldeisers, en dit wel het geval is bij een vergelijkbare conclusie van een onafhankelijke deskundige in het vervolg van de regeling, hangt de bepaling wat in de lucht.

Volgens het tweede lid dragen de lidstaten er zorg voor dat schuldeisers die geen genoegen nemen met de bescherming van hun belangen waarin het voorstel voor de omzetting (of fusie of splitsing) voorziet, de desbetreffende administratieve of gerechtelijke instanties kunnen verzoeken om passende waarborgen binnen één maand na de openbaarmaking van het voorstel. Hoewel de vennootschap in de praktijk vermoedelijk niet snel (aanvullende) waarborgen in het voorstel zal opnemen bij omzetting, is het goed dat wanneer dat wel gebeurt, andere schuldeisers hiervan op de hoogte zijn. Het bieden van aanvullende waarborgen aan één of meer schuldeisers kan immers gevolgen hebben voor de positie van andere schuldeisers.

51. Zie art. 86 duodecies. Zie voor fusie p. 74 , en voor splitsing art. 160 quaterdecies (met in de toelichting, p. 33, per abuis 'de omgezette vennootschap'). Vgl. art. 99 Richtlijn 2017/1132. Zie voor fusie verder par. 4 en voor splitsing verder par. 5 hieronder. Dit lijkt op het regime zoals in Denemarken en Zweden geldt. Zie daarvoor EMCA 2017, p. 267. Zie voor de positie van schuldeisers bij nationale omzetting, fusie en splitsing Verbrugh 2007.

52. Risico's voor schuldeisers bij omzetting kunnen bijv. bestaan uit soepelere regels voor het doen van uitkeringen na omzetting en voor het starten van een procedure tegen de debiteur.

53. Bij splitsing gaat het om 'na redelijke verzoeken om inlichtingen' (art. 160 quaterdecies lid 1). 
Lid 3 werkt twee mogelijke omstandigheden uit waaronder de schuldeisers geacht worden niet door een omzetting (fusie of splitsing) te zijn geschaad. Het gaat hier om twee weerlegbare vermoedens. ${ }^{54}$ Daarvan is allereerst sprake wanneer de vennootschap samen met het voorstel voor de omzetting (fusie of splitsing ${ }^{55}$ ) een verslag van een onafhankelijke deskundige openbaar makkt waarin (voor omzetting) is geconcludeerd dat er geen redelijk vermoeden bestaat dat de rechten van schuldeisers zouden worden geschaad'. Het gaat bij fusie om de conclusie 'dat redelijkerwijs niet te verwachten is dat de rechten van de schuldeisers overmatig zouden worden geschaad', en bij splitsing 'dat het redelijk onwaarschijnlijk is dat de rechten van de schuldeisers onnodig zouden worden geschaad'. Hoewel ook bij andere regelingen, die zowel voor omzetting als voor fusie en splitsing gelden, de precieze bewoordingen regelmatig van elkaar afwijken, zijn de verschillen hier opvallend groot. Uit de toelichting blijkt dat geen inhoudelijke verschillen zijn bedoeld en het er in alle gevallen om gaat dat schuldeisers 'niet benadeeld zijn'. ${ }^{56} \mathrm{Nu}$ het gaat om een voorstel voor een richtlijn die na aanneming in alle lidstaten moet worden omgezet, is het nog belangrijker dan bij nationale wetgeving dat bepalingen duidelijk en consistent zijn. Het tweede bewijsvermoeden geldt wanneer, kort gezegd, aan schuldeisers het recht op betaling wordt verleend dat voor dezelfde rechterlijke instantie kan worden gebracht als hun oorspronkelijke vordering.

De leden 1, 2 en 3 doen niet af aan de toepassing van het nationale recht van de lidstaat van vertrek met betrekking tot het voldoen of het verzekeren van aan overheidsinstanties verschuldigde betalingen, aldus lid $4 .{ }^{57}$

\section{Grensoverschrijdende fusies}

\subsection{Inleiding}

Sinds er een geharmoniseerde grensoverschrijdende fusieregeling geldt in de EU is het aantal fusies sterk gestegen. Het gaat om een stijging van $173 \%$ tussen 2008 en $2012 .{ }^{58}$ Uit eigen onderzoek blijkt dat tussen 2008 en begin 2018 in totaal 779 fusies zijn aangekondigd in de Staatscourant. ${ }^{59}$ Hoewel de Tiende richtlijn uit 2005 nadien is aangepast, gelden voor de praktijk nog steeds diverse problemen. ${ }^{60}$

54. Voorstel, p. 27.

55. Bij splitsing staat per abuis 'het voorstel voor omzetting' (art. 160 quaterdecies lid 3 sub a).

56. Voorstel, p. 27, resp. p. 30 en 33.

57. Ook hier is de formulering bij fusie en splitsing anders dan bij omzetting en gaat het om betalingen aan publiekrechtelijke lichamen. Zie p. 75, nr. 12 en art. 160 quaterdecies lid 5.

58. Voorstel, p. 6.

59. Bij het aantal moet een slag om de arm worden gehouden. Zo waren er over 2016 geen publicaties vindbaar. Overigens gaat het niet om 779 fusies, nu het bij de aankondigingen regelmatig gaat om een fusie binnen een groep met afzonderlijke aankondigingen. Bij meerdere Nederlandse vennootschappen kan (wel) met een gezamenlijke aankondiging worden volstaan (art. 2:333e lid $2 \mathrm{BW}$ ).

60. Zie daarvoor uitgebreid Bech-Bruun \& Lexidale, Study on the application of the Cross-border Mergers Directive, 2013. Zie voorts het richtlijnvoorstel, p. 6-7 en de effectbeoordeling bij het voorstel.

\subsection{Bescherming van (minderheids)aandeelhouders}

In paragraaf 3.3 is het voorstel tot invoering van een algemeen uittreedrecht voor minderheidsaandeelhouders besproken. In de huidige fusieregeling wordt lidstaten de optie geboden minderheidsaandeelhouders passende bescherming te bieden. ${ }^{61}$ Het gevolg hiervan is dat een aantal lidstaten geen specifieke bescherming kent en andere lidstaten bescherming bieden aan alle minderheidsaandeelhouders, of alleen aan minderheidsaandeelhouders van de verdwijnende vennootschap. ${ }^{62}$ In het laatste geval is de ratio van de bescherming dat het toepasselijke vennootschapsrecht met de fusie voor hen wijzigt, hetgeen niet het geval is voor de aandeelhouders van de verkrijgende vennootschap. Daarmee is ook de ratio gegeven voor een uittreedrecht bij grensoverschrijdende omzetting. Nu geen vergelijkbaar uittreedrecht geldt in de Derde richtlijn voor nationale fusies en de (ingrijpende) rechtsgevolgen van een fusie daarmee volgens de Commissie geen aanleiding vormden voor een dergelijk recht, ligt invoering van een uittreedrecht bij de verkrijgende vennootschap bij grensoverschrijdende fusies niet voor de hand. ${ }^{63}$ Andersom geldt dat als een algeheel uittreedrecht voor grensoverschrijdende fusies verplicht zou worden ingevoerd in de lidstaten, het onderscheid met nationale fusies (een stuk) minder goed te verdedigen is. ${ }^{64}$ Verplichte invoering in alle lidstaten van een algemeen uittreedrecht lijkt hiermee dan ook verder te gaan dan nodig is om aandeelhouders te beschermen. Dat gaat ten koste van het faciliteren van de structuurwijziging en verkleint de ruimte voor lidstaten om eigen keuzes te maken. Opvallend is dat de toelichting bij het voorstel slechts aandacht heeft voor gebrek aan harmonisatie bij de bescherming van minderheidsaandeelhouders en niet voor de ratio van een algemeen uittreedrecht. ${ }^{65}$

Nieuw voorgesteld wordt dat de lidstaten waarborgen dat de aandeelhouders die zich niet tegen de fusie hebben verzet, maar de voorgestelde ruilverhouding niet passend achtten, de ruilverhouding voor de nationale rechter kunnen aanvechten. ${ }^{66}$ Eenzelfde regeling wordt voorgesteld voor splitsing. ${ }^{67} \mathrm{De}$ vraag is waarom een aandeelhouder die vanwege de ruilverhouding tegen de fusie is, maar niet wil uittreden, wordt gedwongen zich niet tegen de fusie te verzetten om de ruilverhouding te kunnen aanvechten. Logischer zou zijn om alle aandeelhouders die niet uittreden het recht te geven de ruilverhouding voor de rechter aan te vechten.

61. Zie art. 121 lid 2 Richtlijn 2017/1132.

62. Zie voor dat laatste geval bijv. art. 2:333h BW.

63. Ook in de EMCA 2017, art. 13.30, geldt geen uittreedrecht bij de verkrijgende vennootschap.

64. Zie voor een pleidooi voor een uittreedrecht bij alle fusies M. Wyckaert \& K. Geens, Cross-border mergers and minority protection. An openended harmonization, Utrecht Law Review (4) 2008, afl. 1, p. 40-52.

65. Voorstel, p. 6-7.

66. Zie voorstel, p. 72, nr. 11, sub b. Het voorstel is summier en blinkt niet uit in helderheid. Onder meer in Duitsland bestaat deze mogelijkheid bij fusies. Zie Verbrugh 2007, p. 126. Zie over de ruilverhouding G. van Solinge \& H.J.M.M. van Boxel, Bescherming van minderheidsaandeelhouders bij een grensoverschrijdende fusie, WPNR 2008/6776.

67. Zie art. 160 duodecies lid 5 sub a. 


\section{Maandblad}

Ondernemingsrecht

Een voordeel voor de vennootschap is dat met dit recht vermoedelijk meer aandeelhouders voor de fusie zullen stemmen en daarmee de kans dat de fusie zal worden goedgekeurd groter is. Een dergelijk recht is uiteraard tevens een voordeel voor aandeelhouders die een procedure zullen starten en in het gelijk worden gesteld. Maar een groot nadeel voor de vennootschap en daarmee voor alle stakeholders is dat hiermee meer rechtsonzekerheid over de financiële gevolgen van de fusie ontstaat. Bovendien kunnen na de fusie, waarbij veelal veel aandacht naar de integratie van de ondernemingen zal moeten gaan, juridische procedures volgen. Dezelfde bezwaren gelden voor splitsing. Vermoedelijk zullen vooral activistische aandeelhouders tegen een ruilverhouding willen opkomen, en zullen (enkele) andere aandeelhouders zich hierbij aansluiten. Een minder vergaand recht zou deze nadelen kunnen beperken. Denkbaar is bijvoorbeeld het recht om een ruilverhouding aan te vechten alleen in te voeren wanneer er geen deskundigenverslag is gemaakt. Zoals hierboven bleek, is een dergelijk verslag bij splitsing niet vereist voor kleine en microondernemingen en kan het achterwege blijven bij fusie wanneer alle aandeelhouders daarmee instemmen. Een andere minder vergaande maatregel zou zijn het recht alleen aan aandeelhouders te geven die zich (juist wel) tegen de fusie of splitsing hebben verzet. Met de invoering van een algemeen uittreedrecht is onvrede over de ruilverhouding bovendien minder knellend, nu aandeelhouders die het niet met de ruilverhouding eens zijn, de kans krijgen uit de vennootschap te stappen. Met een verplichte invoering in de lidstaten van dit recht om de ruilverhouding aan te vechten lijkt ook hier de balans tussen facilitering en bescherming te worden verstoord.

\subsection{Bescherming van schuldeisers}

Een van de belangrijkste knelpunten bij fusie komt voort uit het feit dat de bescherming voor schuldeisers verschillend is uitgewerkt in de lidstaten en daarmee niet goed op elkaar aansluit. Kort gezegd gaat het in de lidstaten om bescherming ex ante, bescherming ex post of beide. ${ }^{68}$ Zoals uit paragraaf 3.4 bleek, voorziet het richtlijnvoorstel in een bescherming $e x$ ante, nu schuldeisers binnen een maand na de publicatie van het voorstel passende waarborgen kunnen verzoeken. Met deze uniforme regeling in alle lidstaten zou een belangrijk knelpunt bij fusie worden opgelost (en bij splitsing worden voorkomen).

$\mathrm{Nu}$ het voor schuldeisers veelal lastig te beoordelen is of zij door de fusie (of splitsing) worden benadeeld, wordt hun positie met het richtlijnvoorstel voor een bestuursverklaring, indien door lidstaten vereist, en met het verslag van de deskundige (indien aanwezig), versterkt.

\subsection{Vereenvoudigde fusieprocedure}

Het richtlijnvoorstel pakt tevens het probleem aan van het ontbreken van een snelle procedure (d.w.z. vereenvoudigde procedures voor minder complexe fusies)'. ${ }^{69}$ De huidige fusie-

68. Zie hierover Bech-Bruun \& Lexidale 2013; Van Solinge 1994.

69. Voorstel, p. 6 regeling kent reeds een aantal versoepelingen voor een moeder-dochterfusie, waarbij geen aandelen worden toegekend..$^{70}$ In het voorstel wordt daaraan de fusie door vennootschappen waarvan alle aandelen in handen zijn van één persoon toegevoegd. ${ }^{71}$ Indien de overnemende vennootschap geen aandelen toekent, geldt ook daarvoor een vereenvoudigde procedure. Deze zogenaamde (vereenvoudigde) zusterfusie is in Nederland al mogelijk bij een nationale fusie. ${ }^{72}$

\section{Grensoverschrijdende splitsingen}

\subsection{Inleiding}

Vandaag beschikt minder dan de helft van de lidstaten over nationale regels voor grensoverschrijdende splitsingen van vennootschappen, aldus de toelichting. ${ }^{73}$ Opvallend is dat de risico's van splitsingen volgens de toelichting vergelijkbaar zijn met die van omzettingen, en daarmee de voor omzetting voorgestelde gestructureerde en gelaagde procedure ook voor splitsingen vereist is. Daarbij wordt ook voor splitsing gewezen op de mogelijkheid van misbruik en kunstmatige constructies. ${ }^{74}$ Zoals hierboven bleek, zien de voorstellen om misbruik tegen te gaan op omzetting en splitsing, en niet op fusie. Uit een vergelijking tussen de rechtsgevolgen bij de drie structuurwijzigingen volgt dat splitsing beter te vergelijken is met fusie, met name wat de risico's betreft. In beide gevallen gaat het vermogen immers onder algemene titel over. Doordat vermogen wordt gesplitst, zijn de risico's bij splitsing (zonder wettelijke bescherming daartegen) met name voor schuldeisers groter dan bij fusie.

\subsection{Splitsingsmogelijkheden}

Het meest opvallende aan het richtlijnvoorstel voor splitsing is dat alleen vermogen kan worden afgesplitst op vennootschappen die nieuw worden opgericht. ${ }^{75}$ In overgang van vermogen op reeds bestaande vennootschappen, zoals bij nationale splitsingen mogelijk is, wordt niet voorzien.

In de toelichting wordt deze keuze, die volgens de Commissie op een later moment opnieuw kan worden beoordeeld, gemotiveerd met de opmerking dat risicobeheer bij splitsing door

70. Zie art. 132 Richtlijn 2017/1132, waarin tevens enkele versoepelingen staan bij houderschap van ten minste $90 \%$.

71. Zie p. 67 , sub $\mathrm{f}$ en p. 76 , nr. 16. Voorts voorziet het nieuwe lid 3 van art. 132 in een specifieke referentiedatum voor de openbaarmaking van de fusiestukken wanneer bij geen van de vennootschappen een AVbesluit is vereist. Het deel in sub f over aandelen die in dezelfde verhouding worden aangehouden, ontbreekt op p. 76, nr. 16.

72. Art. 2:333 lid 2 BW. Deze versoepelingen gelden eveneens bij een grensoverschrijdende fusie, maar kunnen tot problemen leiden wanneer het recht van de buitenlandse zuster hierin niet voorziet, aldus Zaman e.a. 2009 , p. 190.

73. Voorstel, p. 8. Volgens EMCA 2017, p. 296, heeft nog geen enkele lidstaat een wettelijke regeling. Zie verder Roelofs 2014.

74. Voorstel, p. 9.

75. Merkwaardig is dat in de definities in art. 160 ter niet is opgenomen dat het gaat om (een) vennootschap(pen) in een andere lidstaat. Daarmee is onduidelijk of beide of een van beide nieuwe vennootschappen in een andere lidstaat moeten zijn gelegen. Aannemelijk is dat één vennootschap voldoende is. 
verwerving zeer complex is. ${ }^{76}$ Bezien vanuit een bestaande verkrijgende vennootschap is een splitsing vergelijkbaar met een fusie. Met de harmonisatie van de fusieregels en de ruime ervaring die daarmee is opgedaan, kan de complexiteit dan ook worden genuanceerd. Nu splitsing van vermogen op bestaande vennootschappen mogelijk is met een beroep op het recht op vrije vestiging, en een belangrijke doelstelling van het voorstel is rechtsonzekerheid weg te nemen, ligt deze keuze ook om die reden niet voor de hand. De kans dat vennootschappen voor deze splitsing van het recht op vrije vestiging gebruik zullen maken, wordt met een geharmoniseerde regeling voor splitsing op nieuwe vennootschappen, die dan analoog kan worden toegepast, zelfs vergroot.

Eveneens opvallend is dat het voorstel tevens ziet op afsplitsing, ${ }^{77}$ nu de Zesde richtlijn daarin niet voorziet. In de toelichting wordt over dit onderscheid met de nationale splitsingsregeling met geen woord gerept.

\subsection{Bescherming van (minderheids) aandeelhouders}

In paragraaf 3 is het voorstel tot invoering van een algemeen uittreedrecht voor minderheidsaandeelhouders besproken en in paragraaf 4 is daaraan een kritische beschouwing toegevoegd voor de verkrijgende vennootschap. $\mathrm{Nu}$ er geen vermogen kan worden afgesplitst op reeds bestaande vennootschappen, komt het uittreedrecht alleen in aanmerking voor aandeelhouders in de gesplitste vennootschap. Omdat het richtlijnvoorstel vennootschappen vrijlaat in de toedeling van aandelen, ${ }^{78}$ geldt - evenals bij fusie - ook bij splitsing dat niet voor alle aandeelhouders hoeft te gelden dat zij (bij een van de vennootschappen) te maken krijgen met buitenlands recht. Als kritische opmerking kan bij splitsing worden toegevoegd dat aandeelhouders ook een uittreedrecht hebben wanneer maar een klein deel van het vermogen wordt afgesplitst, en de gevolgen voor hen daarmee beperkt zullen zijn.

Omdat er alleen vermogen kan worden (af)gesplitst op nieuw op te richten vennootschappen, is het vaststellen van de ruilverhouding minder complex. In die zin lijkt aan de bij fusie besproken mogelijkheid de ruilverhouding voor de rechter aan te tasten minder behoefte. Daar staat bij splitsing tegenover dat vermogen op verschillende vennootschappen overgaat en dat vrijheid wordt geboden in de toedeling van aandelen. Beide maken de vaststelling van de ruilverhouding complexer. Maar gezien de in paragraaf 4.2 genoemde nadelen voor de vennootschappen van het recht de ruilverhouding voor de rechter aan te kunnen tasten, zou een heroverweging ook bij splitsing goed zijn.

\subsection{Bescherming van schuldeisers}

Voor splitsing gelden enkele, op de bij omzetting besproken, aanvullende bepalingen ter bescherming van schuldeisers. De

76. Voorstel, p. 9.

77. Zie art. 160 ter lid 3 sub b en art. 160 duovicies lid 3. De gevolgen voor het aandeelhouderschap in beide artikelen roepen diverse vragen op.

78. Zie daarover verder Roelofs 2014, p. 196 belangrijkste specifieke bescherming bij splitsing is te vinden in artikel 160 quaterdecies lid 4. Daarin is te lezen:

\begin{abstract}
'Wanneer een schuldeiser van de gesplitste vennootschap wiens vordering wordt overgedragen aan/is overgegaan op een verkrijgende vennootschap geen voldoening krijgt van die verkrijgende vennootschap, zijn de andere verkrijgende vennootschappen, en in het geval van een gedeeltelijke splitsing de gesplitste vennootschap, hoofdelijk tot nakoming van die verbintenis gehouden. Het maximumbedrag van de hoofdelijke aansprakelijkheid van een vennootschap wordt beperkt tot de waarde van het nettoactief dat aan die vennootschap op de datum waarop de splitsing van kracht wordt, wordt toegewezen.'
\end{abstract}

Deze bepaling komt grotendeels overeen met de bepaling voor schuldeisers in de Zesde richtlijn. ${ }^{79}$ Een belangrijk verschil is dat voor nationale splitsingen de beperking tot het nettoactief een optie is aan de lidstaten. ${ }^{80} \mathrm{Nu}$ het in het richtlijnvoorstel om grensoverschrijdende splitsing gaat, is eenzelfde regime in de EU op dit punt een groot voordeel. Het betekent wel dat lidstaten een verschillend regime kunnen krijgen voor nationale en grensoverschrijdende splitsingen, afhankelijk van de gemaakte keuzes. Dat geldt ook wanneer een lidstaat gebruik heeft gemaakt van de optie in de Zesde richtlijn voor splitsing onder toezicht van de rechter, in plaats van een aansprakelijkheidsregeling. ${ }^{81}$

Hetzelfde geldt voor de regeling inzake 'vergeten' activa en passiva. ${ }^{82}$ Ook daar geldt een beperking tot het nettoactief in het richtlijnvoorstel en biedt de Zesde richtlijn hiervoor een optie aan de lidstaten. Terecht maakt het voorstel, anders dan de Zesde richtlijn, een onderscheid tussen de toedeling van deze passiva (draagplicht) en de hoofdelijke aansprakelijkheid. ${ }^{83}$ Overigens is de vraag waarom de regeling in het richtlijnvoorstel nodig is, nu het tevens verplicht bij de nauwkeurige beschrijving en verdeling van de activa en passiva in het splitsingsvoorstel een behandeling op te nemen voor deze 'vergeten' onderdelen. ${ }^{84}$

\section{Slot}

In het licht van het actieplan uit 2003 en uit 2010 heeft het lang geduurd voordat de Commissie met een richtlijnvoorstel

79. Art. 147 Richtlijn 2017/1132.

80. Vgl. art. 2:334t BW.

81. Die optie was vooral voor het Verenigd Koninkrijk relevant. Met een brexit zal het Verenigd Koninkrijk niet gebonden zijn aan de nieuwe regels. Andersom betekent een brexit dat het verdere harmonisatieproces geen hinder van deze lidstaat kan ondervinden.

82. Zie art. 137 lid 3 Richtlijn 2017/1132 en art. 160 sexies lid 3. Anders dan in lid 2 over de activa vermeldt lid 3 niet 'en interpretatie van dat voorstel geen uitsluitsel geeft'. Aangenomen moet worden dat dit tevens voor lid 3 geldt, ook omdat een dergelijk onderscheid niet in de Zesde richtlijn wordt gemaakt.

83. De toedeling geschiedt naar evenredigheid. Of daarbij moet worden gekeken naar het nettoactief of het nettopassief is per abuis nog als vraag geformuleerd in het voorstel.

84. Art. 160 sexies lid $1 \mathrm{sub} \mathrm{m}$. Hierin voorziet de Zesde richtlijn niet. 


\section{Maandblad}

voor grensoverschrijdende mobiliteit kwam. Met name voor omzetting werd de roep om een geharmoniseerde regeling steeds luider. Goed nieuws is dat de Commissie met dit voorstel de drie structuurwijzigingen gezamenlijk ter hand neemt. Ongelukkig is daarbij wel dat bij diverse onderwerpen alleen nieuwe regels voor omzetting en splitsing worden voorgesteld, die daarmee uit de pas lopen met de fusieregeling. Daarnaast valt op dat het voorstel veel fouten, slordigheden en inconsistente woordkeuzes en nummering bevat.

Opvallend is de grote aandacht voor bescherming van stakeholders (in ruime zin). Daarmee zwaait de pendule na bijna twee decennia weer terug en kan niet alleen worden gesproken van een nieuw voorstel, maar tevens van een nieuwe benadering in het harmonisatieproces. Wat betreft de beoogde controle op onterechte belastingvoordelen lijkt het voorstel overbodig door de reeds bestaande fiscale Europeesrechtelijke regels. Tevens worden met het voorstel fiscale doelstellingen in civielrechtelijke wetgeving voor structuurwijzigingen binnengehaald. Wat betreft de beoogde controle op kunstmatige constructies die de rechten van stakeholders aantasten, is de vraag of de bevoegde instantie hiertoe goed in staat is. Voor een aantal andere beschermende maatregelen lijkt de balans tussen faciliteren en beschermen wat te ver door te slaan naar de kant van bescherming. Het gaat daarbij onder meer om een grotendeels gelijke bescherming van schuldeisers bij omzetting, fusie en splitsing, om het recht van aandeelhouders de ruilverhouding aan te tasten, en om een algemeen uittreedrecht voor aandeelhouders. Het is te hopen dat de Commissie op korte termijn met een verbeterde versie komt, die vervolgens snel kan worden aangenomen. 